\title{
Kepuasan Pasien dan Kunjungan Rumah Sakit
}

\section{Hafizurrachman*}

\begin{abstract}
Abstrak
Kepuasan pasien ternyata tidak selalu meningkatkan kunjungan pasien di fasilitas pelayanan kesehatan. Penelitian ini bertujuan mengetahui hubungan kepuasan pasien dengan jumlah kunjungan di rumah sakit. Penelitian ini menggunakan data primer survei pelayanan di rawat jalan dan rawat inap selama 9 periode pengukuran pada 2007 - 2009 dan data sekunder kunjungan rumah sakit pada periode yang sama, jumlah sampel adalah 125 pasien per periode yang diambil dengan metoda stratified random sampling. Analisis dilakukan secara analisis time series dengan metode tren kuadrat terkecil (Least Square Method), analisis regresi sederhana dan analisis uji perbedaan tiga atau lebih rata-rata (Uji-Kruskal Wallis). Penelitian ini memperlihatkan tingkat kepuasan pasien berpengaruh terhadap variasi jumlah kunjungan dengan nilai nol pada rawat jalan dan sangat kecil pada rawat inap. Pada rawat jalan tingkat kepuasan pasien tidak berbeda untuk setiap periode, tetapi pada rawat inap berbeda. Terlihat perbedaan tingkat kepuasan pasien rawat jalan dan di rawat inap, tetapi secara statistik diketahui tidak telihat perbedaan tingkat kepuasan antara jumlah kunjungan pasien rawat jalan dan rawat inap pada setiap periode pengukuran di suatu rumah sakit swasta di Tangerang tersebut.
\end{abstract}

Kata kunci : Kepuasan, kunjungan, kualitas, tren

\section{Abstract}

To improve services in order to increase patient satisfaction, does not necessarily means to cease the search for innovative effort to improve the quality of health service hospital. One way to know the value of customers is through customer satisfaction surveys. Based on the customer satisfaction survey it can be known what is the indicators of customer satisfaction and customer expectations, which in turn may increase the expected visit. The purpose of this research is to know the level of patient satisfaction in a private hospital in Tangerang in 2007 until 2009. Survey research design is used to find the differences between the level of satisfaction in out-patient and in-patient services during the 9 period of measurement in 2007-2009, and the secondary data of hospital visit in the same period. Number of sample is 125 patients per period taken with a stratified random sampling. Analysis done in time series analysis methods with the smallest quadratic trends (Least Square Method), simple regression analysis and Kruskal-Wallis test. The result is that the patient satisfaction level affect the number of visits for both types of patient. Among the out-patient, there is no difference found in the level of patient satisfaction among different periods, while the situation is contrary among the in-patient at a private hospital in Tangerang 2007-2009.

Key words : Satisfaction, visits, quality, trends

*Departemen Administrasi Kebijakan Kesehatan Fakultas Kesehatan Masyarakat Universitas Indonesia, Gd. F Lt. 1 FKM UI, Kampus Baru UI Depok 16424 (e-mail: hafizurrachman@centrin.net.id) 
Kebutuhan perusahaan untuk meningkatkan mutu produk/jasa serta kepuasan pelanggan semakin besar karena perdagangan bebas yang terbuka dalam era globalisasi. Oleh sebab itu, perusahaan di dalam negeri diharapkan mempersiapkan diri untuk membina organisasi terutama sumber daya dan sistem untuk menghadapi kedatangan pesaing industri sejenis dan industri lainnya. ${ }^{1}$

Rumah sakit merupakan salah satu perusahaan yang dituntut mampu memenangkan persaingan. Untuk itu, rumah sakit harus mampu menyediakan dan memberikan jasa layanan kesehatan yang bermutu bagi pasien. Pelayanan jasa kesehatan yang bermutu merupakan isu untuk memenangkan persaingan bagi rumah sakit. Selain itu, sebagai upaya rumah sakit untuk menghindari dan mencegah tuntutan masyarakat sesuai dengan Undang-Undang No. 8 Tahun 1999 tentang Perlindungan Konsumen. ${ }^{2}$

Untuk meningkatkan pelayanan dalam rangka meningkatkan kepuasan pasien, pihak-pihak yang berkompeten dengan rumah sakit selalu mencari upaya inovatif untuk meningkatkan mutu layanan kesehatan rumah sakit antara lain dengan mendapatkan sertifikat ISO 9000. ${ }^{3}$ Data kajian pengeluaran publik sektor kesehatan 2007, menggambarkan tren pemanfaatan pelayanan kesehatan pada periode 2001 - 2005 mengalami penurunan daripada sebelum krisis ekonomi periode 1993 - 1997.4 Dengan demikian, rumah sakit yang tidak mampu menjaga kualitas layanan yang berfokus pada kepuasan pelanggan akan mengalami penurunan jumlah kunjungan pasien.

Harapan pasien terhadap kualitas pelayanan yang mereka terima dapat dilihat dari beberapa aspek, meliputi: 1) kemudahan mengakses atau mendapatkan perawatan; 2) tenaga kesehatan yang kompeten dan terampil; 3) kebebasan memilih dokter dan rumah sakit; 4) pengobatan yang sesuai; 5) penjelasan tenaga kesehatan tentang kondisi dan pengobatan/perawatan; 6) penghargaan tenaga kesehatan terhadap klien; 7) perhatian tenaga kesehatan; 8) tenaga kesehatan yang profesional; dan 9) perbaikan kondisi klien setelah perawatan. ${ }^{4}$ Nilai-nilai harapan persepsi pasien terhadap kualitas layanan tersebut yang terdapat dalam diri pelanggan disebut nilai pelanggan (costumer values). ${ }^{6}$ Salah satu cara untuk mengetahui nilai pelanggan adalah melalui survei kepuasan pelanggan. Berdasarkan survei kepuasan pelanggan dapat diketahui berbagai indikator yang menyebabkan pelanggan puas, tidak puas, dan mengetahui keinginan, kebutuhan serta harapan pelanggan. ${ }^{7,8}$

Kualitas jasa pelayanan rumah sakit berdasarkan nilai pelanggan dapat bersifat tidak kasat mata (intangible) seperti keramahan, kecepatan, keterampilan dan komunikasi yang dilakukan oleh petugas pelayanan, maupun yang bersifat kasat mata (tangible) seperti fasilitas yang tersedia menyangkut kebersihan dan kenyamanan serta pelayanan pada instalasi gizi. ${ }^{9}$ Penelitian ini secara umum bertujuan untuk mengetahui gambaran keterkaitan tingkat kepuasan pasien dengan jumlah kunjungan pasien di suatu rumah sakit swasta di Tangerang tahun 2007 sampai dengan 2009.

Penelitian ini diharapkan akan banyak memberikan manfaat baik pihak manajemen rumah sakit tersebut dan karyawannya maupun stakeholders, sehingga berbagai pihak dapat menyusun strategi yang tepat untuk meningkatkan layanan rumah sakit dalam rangka meningkatkan kepuasan pasien rumah sakit tersebut berdasarkan temuan-temuan penelitian serta mempertahankan bahkan meningkatkan jumlah kunjungan pada rumah sakit tersebut. Di samping itu pula, memberikan manfaat kepada pembaca untuk mengetahui apa dan bagaimana keterkaitan jumlah kunjungan ke rumah sakit dengan upaya pemberian kepuasan (patient satisfaction) sehingga jumlah kunjungan dapat dipertahankan dan ditingkatkan.

\section{Metode}

Penelitian ini menggunakan data sekunder survei tingkat kepuasan pelayanan di suatu rumah sakit swasta di Tangerang pada 2007 - 2009 selama 9 periode pengukuran. Pengukuran periode I adalah pada Juni 2007; periode II (Agustus 2007); periode III (September 2007); periode IV (Januari 2008); periode V (April 2008); periode VI (Agustus 2008); periode VII (Januari 2009); periode VIII (April 2009); dan periode IX (Juni 2009). Korelasi time series digunakan untuk melihat keterkaitan jumlah kunjungan dengan tingkat kepuasan yang ada pada periode yang sama selama 9 periode pengukuran.

Populasi penelitian ini adalah seluruh pasien rawat jalan dan rawat inap rumah sakit. Besar sampel per periode adalah 125 orang pasien dengan kriteria inklusi adalah pasien yang pernah melakukan kunjungan rawat inap dan rawat jalan sedangkan kriteria eksklusi adalah pasien yang menolak ikut serta dalam penelitian. Pemilihan sampel dilakukan dengan cara stratified random sampling, terhadap pasien-pasien yang berkunjung ke rumah sakit ini. Sumber data berasal dari data primer dan data sekunder. Data primer adalah pasien yang berkunjung ke rumah sakit, sedangkan data sekunder adalah data hasil kunjungan pasien baik rawat jalan dan rawat inap dari tahun 2007 - 2009.

Instrumen penelitian yang digunakan berupa kuesioner yang berisi butir pertanyaan yang mengukur indikator-indikator kepuasan pelayanan rumah sakit ini, terdiri dari keramahan, kecepatan, keterampilan, komunikasi, kebersihan, kenyamanan dan fasilitas yang ada. Penilaian kuesioner didasarkan atas jawaban responden yang dikelompokkan menurut katagori setuju=1 dan tidak setuju=2 terhadap pernyataan yang ditanyakan. 
Tabel 1. Distribusi Tren Terhadap Kepuasan Pasien Rawat Jalan Menurut Indikator Pembentuk.

\begin{tabular}{lccll}
\hline $\begin{array}{l}\text { Indikator } \\
\text { Pembentuk }\end{array}$ & $\begin{array}{c}\text { Persentase } \\
\text { Rata-rata }\end{array}$ & $\begin{array}{c}\text { Tren } \\
\text { Rata-rata }\end{array}$ & Persamaan Garis & Keterangan \\
\hline Keramahan & 82,4 & $-0,12$ & $\mathrm{Y}=82,42-0,12(\mathrm{X})$ & Menurun \\
Kecepatan & 70,7 & $-0,39$ & $\mathrm{Y}=70,68-0,39(\mathrm{X})$ & Menurun \\
Kebersihan & 84,0 & $-0,57$ & $\mathrm{Y}=80,04-0,57(\mathrm{X})$ & Menurun \\
Kenyamanan & 89,2 & 0,19 & $\mathrm{Y}=89,16+0,19(\mathrm{X})$ & Meningkat \\
Komunikasi & 78,5 & $-0,99$ & $\mathrm{Y}=78,48-0,99(\mathrm{X})$ & Menurun \\
Fasilitas & 76,9 & 1,29 & $\mathrm{Y}=76,89+1,29(\mathrm{X})$ & Meningkat \\
Keseluruhan & 78,1 & $-0,19$ & $\mathrm{Y}=78,10-0,19(\mathrm{X})$ & Menurun \\
\hline
\end{tabular}

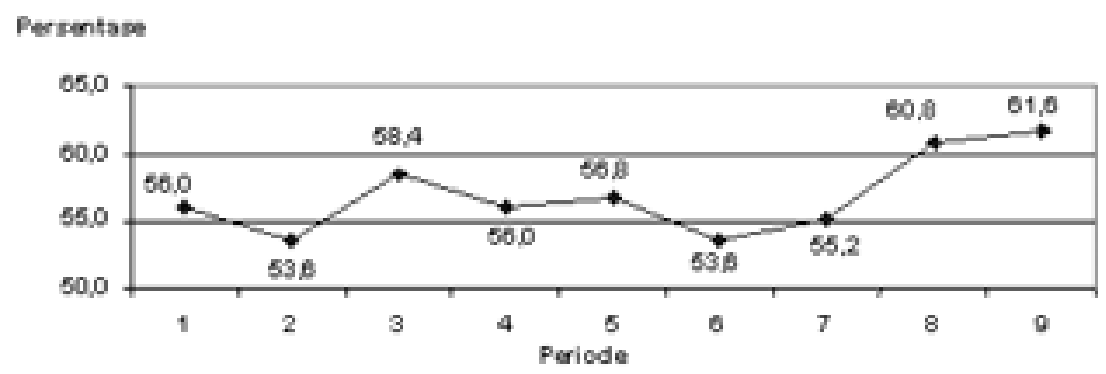

Gambar 1. Tingkat Kepuasan Pasien Layanan Rawat Jalan dari Periode I - IX

Kemudian data yang ada dilihat normalitas distribusinya. Pada data yang berdistribusi normal dilakukan cut off point dengan mean untuk mengetahui gradasi tingkat kepuasan pasien (puas dan tidak puas), sedangkan yang tidak normal dilakukan dengan cut off point dengan median. Sebelum penelitian dilakukan, kuesioner dilakukan uji validitas dan realibitasnya.

Analisis data menggunakan 1) analisis time series dengan metode tren kuadrat terkecil (Least Square Method) yang bertujuan untuk mengetahui tren naikturunnya tingkat kepuasan pasien dan jumlah kunjungan pasien per periode; 2) analisis regresi sederhana yang bertujuan untuk mengetahui keterkaitan naik-turunnya tingkat kepuasan pasien dengan jumlah kunjungan pasien; dan 3) analisis uji perbedaan 3 atau lebih ratarata (Uji-Kruskal Wallis) yang bertujuan untuk mengetahui perbedaan secara signifikan tingkat kepuasan pasien antara periode I sampai dengan periode IX menurut layanan rawat jalan dan rawat inap.

\section{Hasil}

Tingkat Kepuasan

Rawat Jalan

Dengan menggunakan analisis time series metode tren kuadrat terkecil diketahui bahwa rata-rata persentase persepsi pasien terhadap layanan rawat jalan di suatu rumah sakit swasta di Tangerang dari periode I hingga periode IX adalah $78,1 \%$ (pasien memberikan per- nyataan/jawaban setuju). Tren rata-rata mengalami penurunan $0,19 \%$ per periode, artinya persepsi pasien dalam memberikan pernyataan/jawaban setuju menurun $0,19 \%$ per periode (Lihat Tabel 1).

Persentase rata-rata tingkat keramahan petugas memberikan layanan rawat jalan menurut persepsi pasien adalah $82,4 \%$. Tingkat keramahan petugas memberikan layanan rawat jalan dilihat dari tren rata-rata dengan nilai $-0,12$, artinya tren rata-rata tingkat keramahan petugas mengalami penurunan (nilai negatif) per periode. Persamaan garis $\mathrm{Y}=82,42-0,12(\mathrm{X})$, dimana $\mathrm{Y}$ adalah persentase keramahan petugas dan $\mathrm{X}$ adalah periode waktu. Indikator-indikator pembentuk kepuasan pasien layanan rawat jalan ada yang mengalami kenaikan dan penurunan per periodenya. Indikator yang mengalami kenaikan adalah kenyamanan dan fasilitas yang tersedia. Sedangkan, indikator yang mengalami penurunan adalah keramahan, kecepatan, kebersihan dan komunikasi.

Hasil uji normalitas dengan uji One Sample KS pada data persepsi pasien terhadap kepuasan layanan rawat jalan di suatu rumah sakit swasta di Tangerang antara periode I sampai dengan periode IX dihasilkan bahwa antara persepsi kepuasan pasien terhadap layanan rawat jalan antara periode I hingga periode IX mempunyai $\mathrm{p}$ value $<$ alpha 0,05 artinya Ho ditolak. Dengan demikian, dapat dikatakan bahwa normalitas data kepuasan pasien terhadap rawat jalan di suatu rumah sakit swasta di Tangerang tidak berdistribusi secara normal. Setelah di- 
Tabel 2. Distribusi Tren Kepuasan Pasien Rawat Inap Menurut Indikator Pembentuk

\begin{tabular}{lcccc}
\hline Indikator Pembentuk & Persentase Rata-rata & Tren rata-rata & Persamaan Garis & Keterangan \\
\hline Keramahan & 81,8 & 0,23 & $\mathrm{Y}=81,82+0,23(\mathrm{X})$ & Meningkat \\
Kecepatan & 80,2 & 0,09 & $\mathrm{Y}=80,18+0,09(\mathrm{X})$ & Meningkat \\
Keterampilan & 71,0 & $-0,35$ & $\mathrm{Y}=71,02-0,35(\mathrm{X})$ & Menurun \\
Kebersihan \& Kenyamanan & 87,5 & $-0,16$ & $\mathrm{Y}=87,51-0,16(\mathrm{X})$ & Menurun \\
Komunikasi & 81,1 & 0,09 & $\mathrm{Y}=81,08+0,09(\mathrm{X})$ & Meningkat \\
Fasilitas Yan Mak & 72,5 & 0,12 & $\mathrm{Y}=72,53+0,12(\mathrm{X})$ & Meningkat \\
Keseluruhan & 79,7 & 0,07 & $\mathrm{Y}=79,66+0,07(\mathrm{X})$ & Meningkat \\
\hline
\end{tabular}

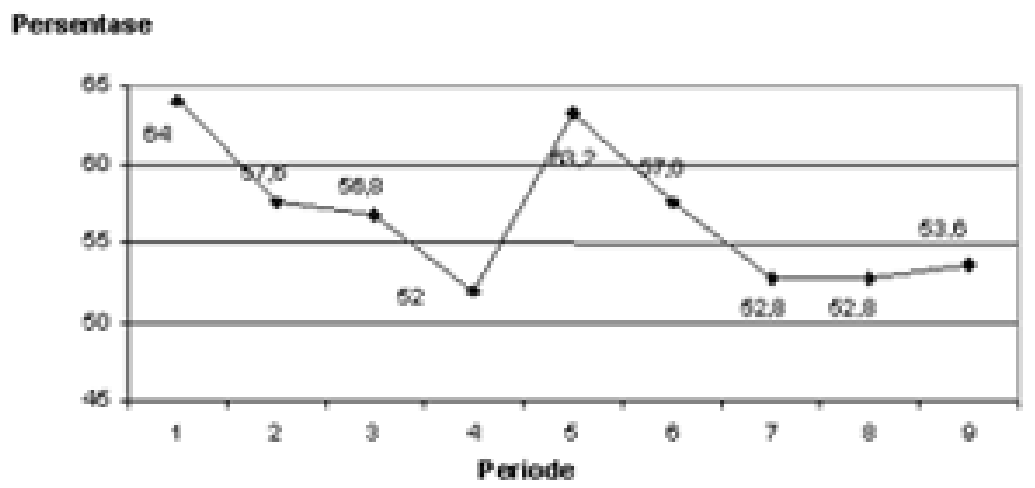

Gambar 2. Tingkat Kepuasan Layanan Rawat Inap dari Periode I - IX

lakukan kategorisasi berdasarkan nilai median (data berdistribusi tidak normal) yakni puas dan tidak puas maka diperoleh hasil bahwa tingkat kepuasan pasien terhadap layanan rawat jalan di suatu rumah sakit swasta di Tangerang antara periode I sampai dengan periode IX mengalami tren turun-naik, dimana tingkat kepuasan yang tertinggi terjadi pada periode IX yakni sebesar $61,6 \%$ dan terendah periode II yakni sebesar $53,6 \%$ (Lihat Tabel 1).

Setelah dilakukan analisis dengan menggunakan metode tren kuadrat terkecil, maka diperoleh persamaan garis $\mathrm{Y}=56,89+0,58(\mathrm{X})$, di mana $\mathrm{Y}$ adalah persentase tingkat kepuasan pasien terhadap layanan rawat jalan dan X adalah periode waktu. Nilai rata-rata tren per periode menunjukkan nilai positif, artinya tingkat kepuasan pasien terhadap layanan rawat jalan menunjukkan peningkatan $\mathrm{r}$ 0,58\% per periode (Lihat Gambar 1).

\section{Rawat Inap}

Dengan menggunakan analisis time series metode tren kuadrat terkecil (Least Square Method) diketahui bahwa rata-rata persentase tingkat kepuasan pasien terhadap layanan rawat inap di suatu rumah sakit swasta di Tangerang dari periode I sampai dengan periode IX adalah $79,7 \%$ (pasien memberikan pernyataan/jawaban setuju). Tren rata-rata mengalami kenaikan sebesar
$0,07 \%$ per periode, artinya persepsi pasien dalam memberikan pernyataan/jawaban setuju mengalami peningkatan 0,07\% per periode (Lihat Tabel 2).

Persentase rata-rata tingkat keramahan petugas dalam memberikan layanan rawat inap menurut persepsi pasien adalah $81,8 \%$. Tingkat keramahan petugas rawat inap dilihat dari tren rata-rata yang mempunyai nilai 0,23 yang berarti tren rata-rata tingkat keramahan petugas mengalami peningkatan (nilai positif) per periode. Persamaan garis $\mathrm{Y}=81,82+0,23(\mathrm{X})$, dimana $\mathrm{Y}$ adalah persentase keramahan petugas dan $\mathrm{X}$ adalah periode waktu. Berbagai indikator pembentuk kepuasan pasien layanan rawat inap setiap periode ada yang naik dan ada yang turun. Indikator yang mengalami peningkatan per periode adalah keramahan, kecepatan, komunikasi, dan fasilitas pelayanan makanan sedangkan indikator yang mengalami penurunan per periode adalah keterampilan, kebersihan dan kenyamanan.

Hasil uji normalitas dengan uji One Sample KS pada data persepsi pasien terhadap kepuasan layanan rawat inap di suatu rumah sakit swasta di Tangerang antara periode I sampai dengan periode IX dapat diketahui bahwa kepuasan pasien terhadap rawat inap antara periode I sampai dengan periode IX mempunyai $p$ value $<$ alpha 0,05 artinya Ho ditolak. Dengan demikian, dapat disimpulkan bahwa normalitas data kepuasan pasien terhadap 


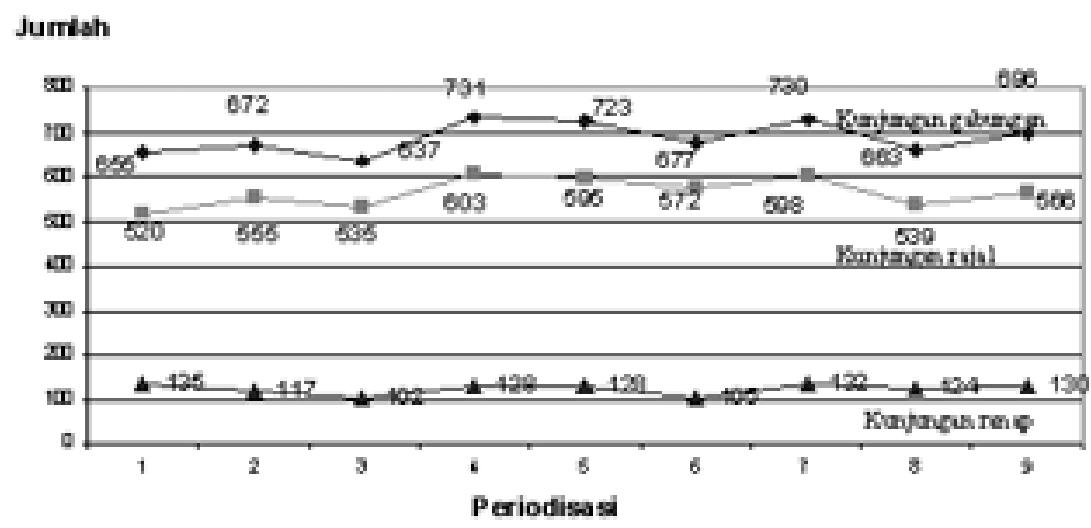

Gambar 3. Kunjungan Pasien pada Layanan RS dari Periode I - IX

rawat inap di suatu rumah sakit swasta di Tangerang tidak berdistribusi secara normal. Setelah dilakukan kategorisasi berdasarkan nilai median (data berdistribusi tidak normal) yakni puas dan tidak puas maka diperoleh hasil bahwa tingkat kepuasan pasien terhadap layanan rawat inap di suatu rumah sakit swasta di Tangerang antara periode I sampai dengan periode IX mengalami turun-naik per periode, dimana tingkat kepuasan yang tertinggi terjadi pada periode I yakni sebesar $64,0 \%$ dan terendah periode IV yakni sebesar 52,0\%.

Setelah dilakukan analisis dengan menggunakan metode tren kuadrat terkecil, maka diperoleh persamaan garis $\mathrm{Y}=56,71-0,97(\mathrm{X})$, dimana $\mathrm{Y}$ adalah persentase tingkat kepuasan pasien terhadap layanan rawat inap dan $\mathrm{X}$ adalah periode waktu. Nilai rata-rata tren per periode menunjukkan nilai negatif, artinya tingkat kepuasan pasien terhadap layanan rawat inap menunjukkan penurunan sebesar 0,97\% per periode (Lihat Gambar 2 ).

\section{Jumlah Kunjungan}

Dengan menggunakan analisis time series metode tren kuadrat terkecil (Least Square Method) diketahui bahwa rata-rata jumlah kunjungan pasien menurut layanan rawat jalan dan rawat inap di suatu rumah sakit swasta di Tangerang adalah 687 kunjungan (jumlah kunjungan rawat jalan dan rawat inap), dimana setiap periode mengalami kenaikan sebesar 4,48 kunjungan per periode dengan persamaan garis $\mathrm{Y}=687,11+4,48(\mathrm{X})$. Dengan demikian, jumlah kunjungan $(\mathrm{Y})$ dengan ratarata kunjungan per periode 687,11 mengalami peningkatan 4,48 kunjungan per periode (X).

Kunjungan tertinggi terjadi pada periode IV yakni sebesar 731 kunjungan dan terendah pada periode I yakni 655 kunjungan. Naiknya jumlah kunjungan pasien pada di suatu rumah sakit swasta di Tangerang per periode disebabkan karena pada kunjungan rawat jalan dengan rata-rata 564,8 kunjungan per periode mengalami kenaikan sebesar 3,85 kunjungan per periode dan pada rawat inap dengan rata-rata 122,3 kunjungan per periode mengalami kenaikan sebesar 0,6 kunjungan per periode (Lihat Gambar 3).

\section{Hubungan Kepuasan dan Jumlah Kunjungan}

Asumsi yang digunakan dalam uji yang dilakukan adalah bahwa apabila kunjungan menurun sering kali dimaknai sebagai akibat proses pemberian kepuasan kepada pasien menurun, sehingga manajer perlu memperbaiki komponen pelayanannya dengan harapan kepuasan meningkat dan akhirnya kunjungan pasien meningkat. Berdasarkan uji regresi linier keterkaitan tingkat kepuasan dengan jumlah kunjungan, maka dapat diperoleh hasil sebagai berikut seperti yang tercantum dalam Tabel 3.

Tingkat keeratan hubungan kepuasan rawat jalan dengan jumlah kunjungan rawat jalan mempunyai keeratan hubungan ( $r$ ) sebesar 0,09 (sangat lemah) dan berpola positif, artinya semakin tinggi kepuasan semakin tinggi jumlah kunjungan. Koefisien determinasi $\left(\mathrm{R}^{2}\right)$ sebesar 0,00 artinya tingkat kepuasan mempengaruhi variasi jumlah kunjungan adalah $0 \%$. Persamaan garis $\mathrm{Y}=574,0-0,118 \mathrm{X}$, dimana $\mathrm{Y}$ adalah jumlah kunjungan rawat jalan dan $\mathrm{X}$ adalah tingkat kepuasan, artinya perubahan besaran nilai y dipengaruhi besaran nilai x. Nilai negatif pada persamaan menunjukkan bahwa tingkat kepuasan menjadi pengurang nilai jumlah kunjungan pasien dan hasil ini bertolak belakang dengan nilai (r) yang mempunyai arah positif. Penyebabnya adalah karena secara signifikan tidak ada hubungan antara kepuasan pasien rawat jalan dengan jumlah kunjungan pasien rawat jalan dengan $p$ value $0,982>$ alpha 0,05 . Juga dapat disimpulkan bahwa tingkat kepuasan pasien rawat jalan tidak berhubungan secara signifikan dengan jumlah 
Tabel 3. Korelasi Tingkat Kepuasan dan Jumlah Kunjungan

\begin{tabular}{lcccc}
\hline Variabel & $\mathbf{r}$ & $\mathbf{R}^{2}$ & Persamaan Garis & p Value \\
\hline Rawat Jalan & 0,09 & 0,000 & $\mathrm{y}=574,0-0,118 \mathrm{x}$ & 0,982 \\
Rawat Inap & 0,42 & 0,173 & $\mathrm{y}=296,751-2,19 \mathrm{x}$ & 0,266 \\
\hline
\end{tabular}

Tabel 4. Uji Kruskal Wallis Perbedaan Tingkat Kepuasan Menurut Periode

\begin{tabular}{lccl}
\hline Variabel & $p$-value & Alpha & Kesimpulan \\
\hline Rawat Jalan & 0,244 & 0,05 & Ho diterima \\
Rawat Inap & 0,006 & 0,05 & Ho ditolak \\
\hline
\end{tabular}

kunjungan pasien rawat jalan, dan tingkat kepuasan pasien rawat inap tidak berhubungan secara signifikan dengan jumlah kunjungan pasien rawat inap (Lihat Tabel $3)$.

\section{Perbedaan Tingkat Kepuasan}

Uji statistik yang digunakan adalah uji statistik non parametrik yakni uji tiga atau lebih sampel yang tidak berhubungan (Uji-Kruskal Wallis), karena data tingkat kepuasan rawat jalan dan rawat inap di suatu rumah sakit swasta di Tangerang tidak berdistribusi normal. Tingkat kepuasan rawat jalan mempunyai $p$ value masing-masing 0,244 > alpha 0,05. Dengan demikian Ho diterima, artinya tidak dapat perbedaan yang signifikan tingkat kepuasan pasien rawat jalan antara periode I sampai dengan periode IX. Sedangkan, tingkat kepuasan pasien rawat inap mempunyai $p$ value $0,006<$ alpha 0,05 (Ho ditolak), artinya ada perbedaan yang signifikan kepuasan pasien rawat inap antara periode I sampai dengan IX (Lihat Tabel 4).

\section{Pembahasan}

Pimpinan rumah sakit yang visioner dan berskala internasional mengharapkan rumah sakit yang dipimpinnya memiliki jumlah kunjungan yang meningkat dari waktu ke waktu disertai dengan pemberian layanan pasien yang berkualitas untuk semua jenis layanan dan memberikan nilai angka patient safety yang tinggi.

Jumlah kunjungan, patient satisfaction dan patient safety sampai batas tertentu untuk jenis penyakit dan pelayanan tertentu sampai batas tertentu pula teoritis berkorelasi kuat, tetapi teori ini dalam tatanan implementasinya bukan pekerjaan mudah bagi pimpinan rumah sakit dalam mewujudkannya, akibat banyak faktor yang berperan. Sementara itu, pada pelayanan sektor barang dan jasa, kecuali jasa rumah sakit, antara jumlah kunjungan dengan kepuasan layanan hampir selalu berkaitan. Jumlah kunjungan akan meningkat, bila klien diberi kepuasan terhadap pelayanan mereka. Karena itu, pemberian layanan dengan prima merupakan iklan gratis yang akan mengundang klien baru. Selanjutnya, jumlah kunjungan yang terus meningkat membuat manajemen harus berupaya mempertahankan tingkat kualitas layanan yang ada, sehingga nilai kepuasan klien yang sudah baik tetap terjaga, hal ini perlu upaya khusus. Manajemen harus menyadari bahwa perilaku klien dari waktu ke waktu selalu berubah, karena perubahan lingkungan sehingga manajemen harus selalu mau mengantisipasinya.

Berangkat dari paradigma di atas, perlu dipahami bahwa penelitian ini mengajarkan dengan membuktikan konsep bahwa dengan paradigma yang ada pada industri rumah sakit tergambarkan bahwa rumah sakit memiliki karakteristik yang unik, sehingga penelitian seperti ini tidak cukup hanya pada satu rumah sakit mengingat rumah sakit di Indonesia memiliki beberapa macam tipe, demikian juga dengan karateristik penggunanya. Namun demikian, penelitian ini dapat menggambarkan fenomena di atas dapat didiskusikan sebagaimana hasil yang ada.

\section{Tingkat Kepuasan Pasien}

Tingkat kepuasan pasien rawat jalan menurut persepsi pasien adalah sebesar 56,9\% yang merasa puas dengan pelayanan rawat jalan di suatu rumah sakit swasta di Tangerang. Indikator pembentuk tingkat kepuasan rawat jalan secara keseluruhan mengalami peningkatan sebesar $0,58 \%$ per periode, artinya setiap periode tingkat kepuasan pasien rawat jalan mengalami kenaikan sebesar $0,58 \%$. Meskipun demikian, berdasarkan indikator pembentuk tingkat kepuasan pada rawat jalan diketahui bahwa keramahan, kecepatan, kebersihan dan komunikasi tren rata-rata mengalami penurunan per periode sedangkan kenyamanan dan fasilitas yang ada mengalami peningkatan per periode.

Upaya yang perlu dilakukan oleh pihak manajemen di suatu rumah sakit swasta di Tangerang untuk meningkatkan kepuasan pasien rawat jalan adalah dengan melakukan perbaikan terhadap indikator yang menurun dan mempertahankan terhadap indikator yang meningkat.

Upaya untuk meningkatkan keramahan, kecepatan dan komunikasi bagi petugas dapat dilakukan dengan melakukan pelatihan (training) bagi petugas. Sedangkan, untuk meningkatkan kebersihan terhadap fasilitas rawat jalan dapat dilakukan dengan lebih mengintensifkan upaya petugas cleaning service untuk bekerja lebih giat atau supervisi yang intensif disamping upaya pihak rumah sakit untuk mengajak pasien/pengunjungnya menjaga kebersihan lingkungan rumah sakit.

\section{Kepuasan Rawat Inap}

Tingkat kepuasan pasien rawat inap menurut persepsi pasien adalah sebesar $56,7 \%$ yang merasa puas dengan 
pelayanan rawat inap di suatu rumah sakit swasta di Tangerang. Indikator pembentuk tingkat kepuasan rawat inap secara keseluruhan mengalami penurunan sebesar $0,97 \%$ per periode, artinya setiap periode tingkat kepuasan pasien rawat inap mengalami penurunan sebesar $0,97 \%$. Meskipun demikian, berdasarkan indikator pembentuk tingkat kepuasan pada rawat inap diketahui bahwa tren rata-rata keramahan, kecepatan, komunikasi dan fasilitas yang ada mengalami peningkatan per periode sedangkan keterampilan, kebersihan dan kenyamanan mengalami penurunan per periode.

Upaya yang perlu dilakukan oleh pihak manajemen di suatu rumah sakit swasta di Tangerang untuk meningkatkan kepuasan pasien rawat jalan adalah dengan melakukan perbaikan terhadap indikator yang menurun dan mempertahankan terhadap indikator yang meningkat.

Upaya untuk meningkatkan keterampilan, bagi perawat dapat dilakukan dengan melakukan pelatihan (training) bagi perawat. Sedangkan, untuk meningkatkan kebersihan dan kenyamanan terhadap fasilitas rawat inap dapat dilakukan dengan lebih mengintensifkan upaya petugas cleaning service untuk berkerja lebih giat bekerja atau supervisi yang intensif di samping upaya pihak rumah sakit untuk mengajak pasien/pengunjungnya menjaga kebersihan ruangan perawatan rumah sakit.

\section{Jumlah Kunjungan Pasien}

Jumlah kunjungan pasien di suatu rumah sakit swasta di Tangerang antara periode I sampai dengan IX rataratanya adalah 687 kunjungan per periode. Tren ratarata jumlah kunjungan mengalami kenaikan 4,48 kunjungan per periode. Peningkatan tren rata-rata jumlah kunjungan disebabkan karena tren rata-rata jumlah kunjungan rawat jalan mengalami kenaikan sebesar 3,85 kunjungan per periode dan kunjungan rawat inap mengalami kenaikan sebesar 0,6 kunjungan per periode.

Meskipun dilihat dari tren rata-rata jumlah kunjungan pasien mengalami peningkatan baik dari rawat jalan dan rawat inap, namun bila dilihat dari tingkat kepuasan pasien pada rawat inap mengalami penurunan per periode. Menurunnya tingkat kepuasan pasien rawat inap dapat berakibat pada menurunnya jumlah kunjungan pasien karena tingkat kepuasan pasien yang rendah mengakibatkan pasien tidak akan menggunakan jasa layanan kesehatan yang disediakan dan pasien dapat saja bercerita kepada kerabat, teman dan lainnya untuk tidak menggunakan jasa layanan kesehatan yang disediakan oleh di suatu rumah sakit swasta di Tangerang.

\section{Hubungan Kepuasan dan Jumlah Kunjungan Pasien}

Tingkat kepuasan pasien rawat jalan secara umum diketahui meningkat $0,58 \%$ per periode dan jumlah kunjungan pasien rawat jalan diketahui meningkat 3,85 kun- jungan per periode. Berdasarkan hasil ini, maka dapat dikatakan bahwa naiknya tingkat kepuasan pasien rawat jalan berdampak pada meningkatnya jumlah kunjungan pasien rawat jalan. Namun demikian, setelah dilakukan analisis regresi sederhana didapatkan hasil bahwa asumsi naiknya tingkat kepuasan rawat jalan yang akhirnya akan diikuti oleh naiknya jumlah kunjungan rawat jalan secara signifikan tidak berhubungan dengan $p$ value $0,982>$ alpha 0,05 .

Sementara itu, tingkat kepuasan pasien rawat inap secara umum diketahui menurun $0,97 \%$ per periode dan jumlah kunjungan pasien rawat inap diketahui meningkat sebanyak 0,6 kunjungan per periode. Berdasarkan hasil ini, maka dapat dikatakan bahwa turunnya tingkat kepuasan pasien rawat berdampak pada naiknya jumlah kunjungan rawat inap (berbanding terbalik). Namun demikian, setelah dilakukan analisis regresi sederhana didapatkan hasil bahwa asumsi turunnya tingkat kepuasan rawat inap yang akhirnya akan diikuti oleh naiknya jumlah kunjungan secara signifikan tidak berhubungan dengan $p$ value $0,266>$ alpha 0,05 .

Dengan demikian, dapat disimpulkan bahwa kenaikan jumlah kunjungan pasien pada di suatu rumah sakit swasta di Tangerang ini, tidak diikuti dengan meningkatnya tingkat kepuasan pasien pada rawat jalan dan rawat inap, artinya antara kunjungan dan tingkat kepuasan pasien yang ada tidak jelas keterkaitannya dan berjalan sendiri-sendiri.

\section{Uji Perbedaan}

Hasil uji statistik non parametrik metode Kruskall Wallis untuk menilai perbedaan rata-rata nilai mean periode I sampai dengan periode IX menurut jenis layanan yang tersedia meliputi nilai rata-rata tingkat kepuasan pasien rawat jalan per periode tidak berbeda secara bermakna, nilai rata-rata tingkat kepuasan pasien rawat inap per periode berbeda secara bermakna. Perbedaan tingkat kepuasan pasien tersebut disebabkan oleh intervensi pihak manajemen rumah sakit swasta meningkatkan berbagai indikator pembentuk kepuasan pasien pada layanan rawat jalan dan rawat inap yang meliputi keramahan, kecepatan, keterampilan, komunikasi, kebersihan, kenyamanan dan fasilitas. Dengan demikian, femomena yang unik tentang perbedaan antar periode dapat dijelaskan sebagai inkonsistensi dan perbedaan karakter individu. Perbedaan pemahaman terhadap perasaan mereka tentang penilaian kepuasan.

\section{Kesimpulan}

Di suatu rumah sakit swasta di Tangerang, pada periode 2007-2009 ditemukan: (1) Data kepuasan pasien terhadap rawat jalan dan rawat inap tidak berdistribusi secara normal. (2) Persentase indikator pembentuk kepuasan pasien layanan rawat jalan dan rawat inap ada 
yang mengalami peningkatan dan penurunan per periode. (3) Nilai rata-rata tren per periode yang positif mengindikasikan tingkat kepuasan pasien rawat jalan per periode yang meningkat, tetapi pada pasien rawat inap tidak. (4) Rata-rata jumlah kunjungan fasilitas pelayanan rawat jalan dan rawat inap per periode memperlihatkan tren yang yang meningkat. (5) Tingkat kepuasan mempengaruhi jumlah kunjungan rawat jalan $0 \%$ dan rawat inap $0,17 \%$. Tingkat kepuasan pasien rawat jalan pada setiap periode tidak berbeda, sementara pada rawat inap berbeda. Dengan demikian, meskipun ada perbedaan tingkat kepuasan pasien di rawat jalan dan rawat inap, tetapi secara statistik tidak bermakna.

\section{Saran}

Meningkatkan kepuasan pasien memerlukan intervensi pada berbagai indikator pembentuk kepuasan pelayanan rawat jalan dan rawat inap meliputi: (1) Pihak manajemen perlu merencanakan program pendidikan dan pelatihan karyawan pelayanan rawat jalan dan rawat inap. Program pendidikan dan pelatihan bertujuan meningkatkan keramahan, kecepatan, komunikasi mereka terhadap pasien/pengunjung RS dan bagi rawat inap untuk meningkatkan keterampilan. (2) Perlu melakukan evaluasi kebersihan dan kenyamanan fasilitas dan mengajak pasien selaku menjaga kebersihan dan kenyamanan lingkungan rumah sakit dengan menggunakan media stiker, poster, spanduk dan lain-lain. (3) Mengambil opsi pengambilan keputusan meningkatkan jumlah kunjungan dengan memahami perilaku pasien. (3) Perlu gagasan menciptakan produk layanan baru dan meningkatkan pelayanan setiap indikator kepuasan di rumah sakit melalui survei kepuasan dan pembentukan lembaga Customer Relation Management (CRM). Untuk penelitian selanjutnya, (1) Perlu mengukur berbagai faktor yang mempengaruhi kepuasan pasien. (2) Mempertahankan survei kepuasan dengan memperbaiki kriteria sampling dan memperbanyak jumlah sampel. (3) Untuk keperluan generalisasi perlu menambah jenis dan jumlah rumah sakit yang diteliti serta perbaikan desain dan metoda analisis.

\section{Daftar Pustaka}

1. Moelyono D. Budaya korporat dan keunggulan korporasi. Edisi Revisi. Jakarta: PT. Elex Media Komputindo; 2004.

2. Undang-Undang No. 8 Tahun 1999. Tentang Perlindungan Konsumen [diakses tanggal 22 Februari 2006]. Diunduh dari: http://www.infolib.ui.edu//.

3. ISO. Quality Management System ISO 9000:2000 [edisi 2001]. Diunduh dari: http://www.iso.ch//.

4. Kajian Pengeluaran Publik Sektor Kesehatan Tahun 2007.

5. Oerman. Costumers description of quality health care [edisi 1999]. Diunduh dari: http://www.proquest.umi.com/pqdweb//.

6. Kotler P. Marketing management, Prentice Hall. Inc. New York, USA: Englewood Cliff; 1994.

7. Tjiptono F dan Chandra G. Quality and satisfaction. Yogyakarta: Andi; 2005.

8. Rangkuty F. Measuring customer satisfaction. Jakarta: PT. Gramedia Pustaka Utama; 2008.

9. Gaspersz V. Organizational excellence. Jakarta: PT. Gramedia Pustaka Utama; 2008.

10. Zeithamal V. Delivering quality service: balancing costumer perceptions and expectations. New York: The Free Press; 2004. 